\title{
SEKSUALITAS DAN RELASI LAKI-LAKI PEREMPUAN DALAM SAJAK "PERSETUBUHAN KUNTHI" KARYA GOENAWAN MOHAMAD
}

\author{
Baban Banita, Lina Meilinawati Rahayu, \& Ari J. Adipurwawidjana \\ Universitas Padjadjaran, Sumedang \\ email: banban_banita@yahoo.com
}

\begin{abstract}
(Title: Sexuality and Relation Man's and Woman's in the Poem "Persetubuhan Bumi" by Goenawan Mohamad). Inequality between woman and man in asexual relationship appear many time in Indonesia's poetry. Women are often being put in a second position even though they have the same competence and power with men. It also happens in relationship on daily activities, both at public space or at home. Women are often connected to a domestic work and have to do many things as away to prove her devotion to men. This affected even to the most private relation between men and women. Women often positioned as a tool to satisfy men's sexual desire. In Goenawan Mohamad's poems, he displays sexuality and relation between men and women in a unique and beautiful way. In this relationship, women are still put in second position, althought the woman genuinely enjoy and satisfied from the sexual activity. Women are shown as a passive body in the hand of men's power. This research is using theory of intertextual and gender. This research shows that there are many factors that created inequality between men and women in a subject of sexual relationship.
\end{abstract}

Keywords: sexuality, relation, intertextual, feminist.

\section{PENDAHULUAN}

Dalam hubungan cinta, lelaki mempunyai posisi yang kuat dan tetap mempunyai keinginan untuk memiliki kekasihnya itu. Menurut Beauvoir (2016), di dalam kehidupan yang sesungguhnya lelaki tetap sebagai subjek-subjek utama; perempuan yang dicintainya hanyalah satu nilai di antara yang lainnya; mereka berharap mengintegrasikannya ke dalam eksistensi mereka dan bukannya menyia-nyiakannya seluruhnya demi perempuan. Sebaliknya bagi perempuan, mencintai berarti menyerahkan segalanya demi kebahagiaan sang tuan. Seperti yang dikatakan Celile Sauvage (Beauvoir, 2016) bahwa perempuan harus melupakan personalitasnya saat jatuh cinta. Ini adalah hukum alam. Seorang perempuan tidak ada artinya tanpa seorang tuan. Tanpa seorang tuan, ia adalah sebuah karangan bunga yang tercecer.

Hubungan yang tidak sejajar ini tidak saja berlaku dalam kehidupan yang bisa dilihat oleh publik, bahkan hubungan yang sifatnya pribadi (hubungan seksual) tidak terlepas dari pengaruh posisi subjek yang berkuasa dan objek yang dikuasainya.

Aktivitas seksual merupakan kegiatan sepasang manusia; laki-laki dan perempuan dalam rangka memenuhi kebutuhan biologisnya atau kebutuhan untuk melepas nafsu syahwat. Selain itu, aktivitas seksual juga merupakan upaya dalam rangka menghasilkan keturunan dan dalam keyakinan 
beragama nafsu yang sering disebut sebagai keinginan purba ini merupakan karunia dari Tuhan yang disertai juga dengan berbagai syarat. Sejatinya aktivitas seksual seharusnya merupakan kegiatan berbagi nikmat dan rasa nyaman bagi pelakunya baik selama proses sedang berlangsung juga setelah hubungan tersebut selesai. Akan tetapi, kegiatan intim yang sangat pribadi ini kadang tidak sepenuhnya dinikmati oleh sebagian pasangan, terutama perempuan. Hal ini biasanya disebabkan oleh perbedaan derajat hubungan yang secara sosial diciptakan dalam suatu masyarakat. Jadinya, kegiatan yang semestinya dinikmati dan menjadi sumber rasa nyaman bagi pasangan yang melakukannya malah menjadi tekanan (penderitaan) bagi satu pasangannya (perempuan).

Karya sastra merekam banyak aktivitas seksual di masyarakat. Hasilnya ada yang menjadi karya yang indah dan menjadi bagian penting untuk dibaca bahkan sebagai sarana pendidikan tapi banyak juga yang menjelma jadi karya yang kental muatan pornografinya dan tidak penting untuk dibaca bahkan sering dilarang oleh pemerintah karena muatan seksualitas yang diungkapkannya tidak memberi memberi pelajaran positif, nilai keindahan, dan lebih cenderung mengumbar proses bersenggama secara vulgar dengan kata-kata yang tanpa metafor dan tidak mengenal etika.

Sajak-sajak karya Goenawan Mohamad banyak yang bertemakan hubungan laki-laki dan perempuan. Hubungan tersebut di antaranya mengungkapkan aktivitas seksual laki-laki dengan perempuan. Hal ini sangat menarik karena aktivitas seksual diungkapkan dengan cara yang berbeda dengan karya lainnya. Selain itu, kisah laki-laki dan perempuan yang menjalani kegiatan seksual justru menjadi lebih penting karena ada pebedaan-perbedaan yang mengarah ke posisi menguasai dikuasai, perbedaan nasib setelahnya, perbedaan derajat di antara keduanya.

\section{TEORI INTERTEKSTUAL}

Sebuah teks tidak sepenuhnya berdiri sendiri. Dia selalu berkaitan dengan teks-teks lain. Penelitian ini akan menggunakan teori intertekstual, yakni sebuah teori atau sebuah istilah yang diciptakan oleh Julia Kristeva. Istilah interteks pada umumnya dipahami sebagai hubungan suatu teks dengan teks lain. Menurut Kristeva tiap teks merupakan sebuah mozaik kutipan-kutipan, tiap teks merupakan penyerapan dan transformasi dari teks-teks lain. Hal ini berarti bahwa sebuah teks tercipta atas pengaruh dari teks-teks lain sebagai bahan dasar penciptaan. Dalam hal ini, pengarang telah mengambil bahan-bahan lain untuk penciptaan yang disusun dan diberi variasi sesuai dengan keperluannya sehingga menghasilkan teks baru atau karya baru. Artinya teks yang satu selalu berkaitan dengan teks lainnya, pembacaan suatu teks selalu menghadirkan teks lain sebagai contoh, teladan, maupun sebagai kerangka acuan. Teks yang baru meneladani, menanggapi, dan menentang teks lama. Inilah yang dinamakan prinsif intertekstual (Culler, 1975:139).

Ada dua alasan penting yang dikemukakan Kristeva berkait dengan hal di atas. Pertama, penulis adalah seorang pembaca teks sebelum menjadi pencipta teks. Ini berarti bahwa seorang penulis menggunakan teksteks lain sebagai rujukan, baik secara langsung ataupun sebaliknya. Kedua, sebuah teks tersedia hanya melalui proses pembacaan (Worton, 1990:1).

Pendapat di atas senada dengan pendapat Riffaterre yang mengemukakan bahwa di dalam teks ada tanda-tanda yang mendua 
artinya secara tekstual kata-kata itu tidak hadir, tetapi pembaca harus menyimpulkannya sendiri. Pembaca harus melihat ke tempat lain untuk memperoleh satu interpretasi kedua. Jadi, interpretasi kedua harus menghadirkan teks lain sebagai tiruannya (1978:94).

Intertekstual menurut Kristeva mempunyai prinsip dan kaidah tersendiri dalam meneliti sebuah karya sastra, yakni: (1) interteks melihat hakikat sebuah teks yang di dalamnya terdapat berbagai teks; (2) interteks menganalisis sebuah karya itu berdasarkan aspek yang membina karya tersebut, yaitu unsur-unsur di luar struktur seperti unsur sejarah, budaya, agama yang menjadi bagian dari komposisi teks; (3) interteks mengkaji keseimbangan antara aspek dalaman dan aspek luaran dengan melihat fungsi dan tujuan kehadiran teks-teks tersebut; (4) teori interteks juga menyebut bahwa sebuah teks itu tercipta berdasarkan karya-karya yang lain. Kajian tidak hanya bertumpu pada teks yang dibaca, tetapi meneliti teks-teks lainnya untuk melihat aspek-aspek yang meresap ke dalam teks yang ditulis atau dibaca atau dikaji; (5) yang dipentingkan dalam interteks adalah menghargai pengambilan, kehadiran, dan masuknya unsur-unsur lain ke dalam sebuah karya (Napiah, 1994:XV).

Senada dengan Kristeva, seorang pemikir Rusia, Mikhail Bakhtin mengatakan bahwa tidak ada ungkapan yang tidak berkaitan dengan ungkapan lainnya. Bakhtin secara implisit menyebutkan bahwa sebuah teks diproduksi dalam suatu proses komunikasi. Suatu teks dihasilkan bukan sebagai monolog pengarang, bukan pula suatu refleksi diri pengarang secara utuh dalam suatu proses referensi diri. Dengan demikian teks menurut Kristeva harus dibaca dengan latar belakang teks-teks lain; tidak ada sebuah teks pun yang sungguh-sunggguh mandiri, dalam arti bahwa penciptaan dan pembacaannya tidak dapat dilakukan tanpa adanya teks-teks lain sebagai contoh, teladan, kerangka; tidak dalam arti bahwa teks baru hanya meneladan teks lain atau mematuhi kerangka yang telah diberikan lebih dulu; tetapi dalam arti bahwa dalam penyimpangan dan transformasi pun model teks yang sudah ada memainkan peranan yang penting (Teuuw, 1984:145-146).

Intertekstual menurut Kristeva adalah hakikat suatu teks yang di dalamnya terdapat teks lain (Yunus, 1985:87). Dengan kata lain, intertekstual adalah kehadiran suatu teks pada suatu teks lain. Dan jika dalam suatu teks ada berbagai teks lain, maka teks itu mungkin saja bersifat karnaval. Hal ini bisa dirumuskan sebagai berikut. Pertama, kehadiran secara fisikal suatu teks dalam suatu teks lainnya. Kedua, pengertian teks bukan hanya terbatas kepada cerita, tapi mungkin berupa teks bahasa. Tapi, kehadiran teks lain dalam suatu teks itu mungkin saja tidak bersifat fisikal belaka, dengan menampilkan (secara eksplisit) (judul) cerita itu sendiri. Namun mungkin dapat dikesan adanya hal-hal sebagai berikut. Keempat, adanya petunjuk yang menunjukkan hubungan-persambungan dan pemisahan, antara suatu teks dengan teks yang telah terbit lebih dulu. Dengan begitu, bukan tidak mungkin penulisnya (telah) membaca suatu teks yang terbit lebih dulu dan kemudian "memasukkannya" ke dalam teks yang ditulisnya.

Kelima, dalam membaca suatu teks, kita tidak hanya membaca teks itu saja, tapi kita membacanya "berdampingan" dengan teksteks lainnya, sehingga interpretasi kita terhadapnya tak dapat dilepaskan dari tekstekslain itu (Yunus, 1985:87-89).

Dalam kesemua hubungan itu, kehadiran suatu teks lain bukanlah suatu yang polos (innocent), yang tidak melibatkan suatu proses 
pemahaman dan pemaknaan, suatu signifying process seperti yang juga dikatakan Kristeva (1980:15). Karena itu, di sini selalu ikut unsur pemaknaan dan bagaimana seseorang menerima teks itu. Dengan interteks dapat dilihat berbagai kemungkinan lain.

Kehadiran teks lain dalam interteks menurut Yunus (1985:89) akan memberikan beberapa pertanyaan: (a) apakah fungsi teks asing itu? (b) bagaimana seorang penulis memperlakukan teks asing itu?

Proses intertekstualitas akan lebih kentara fungsinya ketika membaca suatu teks. Teks tidak pernah menjadi teks yang sepenuhnya bebas. Ketika dibaca, teks-teks itu berdampingan dengan teks-teks lain, intertextuell menurut Pavis, sehingga teks-teks lain itu, bersama-sama dengan ideotext, akan menentukan penerimaan kita terhadap suatu teks.

Membaca pada dasarnya adalah membina atau membentuk acuan. Acuan itu diperolehnya dari pengalaman membaca teks lain dalam sistem konvensi kesastraan. Suatu teks penuh makna bukan hanya karena mempunyai struktur tertentu, melainkan juga karena teks itu berhubungan dengan teks lain. Suatu teks lahir dari teks-teks lain dan karena itu harus dipandang sesuai dengan posisinya dalam kawasan tekstual (Sardjono, 1986: 60). Inilah yang disebut intertekstualitas atau hubungan antarteks. Pengertian, paham, atau prinsip ini berasal dari aliran strukturalisme Perancis yang dipengaruhi oleh pemikiran filsuf Jacques Derrida.

Prinsip intertekstualitas berarti bahwa setiap teks sastra harus dibaca dengan latar belakang teks-teks lain. Dalam konteks ini, tidak ada suatu teks pun yang sungguhsungguh mandiri; penciptaan dan pembacaannya tidak dapat dilakukan tanpa adanya teks lain sebagai contoh, teladan, atau kerangka; dalam penyimpangan atau trans- formasi, model teks yang sudah ada memainkan peranan penting. Pemberontakan atau penyimpangan mengandaikan adanya sesuatu yang dapat diberontaki atau disimpangi, dan pemahaman teks baru memerlukan latar belakang pengetahuan tentang teks-teks yang mendahuluinya (Teeuw, 1988: 145-146).

Culler (1981: 103) mengemukakan bahwa intertekstualitas pada hakikatnya memiliki fokus ganda: (1) meminta perhatian kita tentang pentingnya teks yang terdahulu (prior text); (2) dalam hubungannya dengan fokus arti, intertekstualitas membimbing kita untuk mempertimbangkan teks terdahulu sebagai penyumbang kode yang memungkinkan lahirnya pelbagai efek signifikasi. Dengan demikian, konsep intertekstualitas sentral bagi setiap deskripsi semiotik signifikasi sastra.

Laurent Jenny dalam salah satu artikelnya menyatakan bahwa intertekstualitas memperlihatkan masalah yang sulit diidentifikasi. Menurutnya, penanda kehadiran sebuah teks dalam teks lain harus dinyatakan dengan tegas. Untuk itu, ia mengusulkan pembedaan antara "intertekstual murni" dengan "kiasan sederhana atau kenang-kenangan" (Culler, 1981: 104).

Sementara itu, Riffaterre mencoba menggunakan konsep intertekstual untuk mendiskusikan referensialitas sastra secara khusus. Salah satu teori Riffaterre yang cukup penting ialah konsepsi tentang kesatuan semiotik. Pada level signifikasi tertinggi, segala sesuatu yang terdapat dalam karya sastra adalah varian 'kata' atau 'kalimat' yang orisinal. Karya sastra adalah hasil transformasi 'kata' atau 'kalimat' tertentu dalam teks. 'Kata' atau 'kalimat' itu adalah matriks (inti). Matriks mungkin dilambangkan dalam satu 'kata'. Dalam kasus ini 'kata' tersebut tidak muncul dalam teks, tetapi diaktualisasikan dalam varian. Bentuk pertama yang dikuasai oleh 
aktualisasi adalah model dan model inilah yang selanjutnya berkembang menjadi teks. Selanjutnya, dijelaskan oleh Riffaterre bahwa matriks dan model teks adalah varian dari struktur yang sama. Oleh karena itu, teks baru menjadi utuh apabila teks tersebut dikaitkan dengan hipogram. Hipogram mungkin suatu klise, kutipan, atau sekelompok asosiasi konvensional yang disebut sistem deskripsi atau kompleks tematik. Sebagai landasan bagi penciptaan karya baru, hipogram mungkin dipatuhi tetapi mungkin juga disimpangi oleh pengarang (Culler, 1981: 107).

Berdasarkan prinsip intertekstual yang dikemukakan Riffaterre (1978), sajak biasanya baru bermakna penuh dalam hubungannya dengan karya lain yang menjadi latar penciptaannya, baik dalam hal persamaannya atau pertentangannya. Artinya, bahwa teks atau sajak yang dianalisis memerlukan pembacaan yang bolak-balik antara sajaknya dengan teks lain yang menjadi hipogramnya atau interteksnya.

\section{KONSEP GENDER}

Konsep gender pada umumnya dikaitkan dengan kontruksi peran yang didapatkan lakilaki dan perempuan dalam sistem masyarakat yang kemudian juga meluas pada relasi yang terjadi di antara kedua jenis kelamin tersebut. Persoalan yang berkaitan dengan gender ini menurut Adji (2017) menjadi semakin kental ketika dalam relasi gender tersebut terjadi ketimpangan yang di dalamnya terdapat hubungan subordinatif. Penyebab timpangnya relasi yang terbangun antara laki-laki dan perempuan ditengarai disebabkan oleh sistem patriarki.

Hubungan laki-laki dengan perempuan ini, terutama jika dikaitkan dengan cinta, semakin menunjukkan bahwa ketimpangan memang tampak jelas. Menurut Byron dalam
Beauvoir (2016), cinta dan kehidupan lakilaki adalah sesuatu yang berbeda; sementara bagi perempuan adalah keseluruhan eksistensi. Nietzsche dalam Beauvoir (2016) mengungkapkan pikiran yang sama bahwa satu kata cinta sebenarnya menerangkan dua hal yang berbeda bagi laki-laki dan perempuan. Bagi perempuan cinta tidak hanya kesetiaan, cinta adalah penyeahan total akan tubuh dan jiwa, tanpa pamrih, tanpa harapan mendapatkan imbalan apapun. Sementara bagi laki-laki jika mencintai perempuan, apa yang ia inginkan hanyalah cinta dari perempuan sebagai konsekuensinya ia jauh dari mendalilkan perasaan yang sama baginya seperti pada perempuan. Tidak ada hasrat kepasrahan total kecuali laki-laki itu tidak akan menjadi lakilaki.

Hubungan laki-laki dan perempuan dalam sistem patriarki tidak digambarkan sebagai hubungan dengan entitas masing-masing. Akan tetapi, salah satu gender (perempuan) digambarkan identitasnya dalam hubungannya dengan laki-laki. St. Thomas Aquinas mengatakan bahwa perempuan adalah laki-laki yang tidak sempurna (Selden, 1993: 135)

Selama ini keseluruhan tubuh perempuan digambarkan dan diberi identitas oleh sistem patriarki sehingga perempuan tidak bisa memberi identitas terhadap dirinya sendiri. Selain itu, identitas perempuan selalu berhubungan dengan identitas laki-laki. Artinya, keberadaan perempuan ditentukan dalam hubungannya dengan laki-laki, bukan karena mereka memiliki identitas sendiri. Laki-laki menjadi ukuran dan standar untuk mendefinisikan dan menentukan kodrat perempuan, bukan perempuan yang diukur atas kualitas yang dimilikinya sendiri. Hal ini sejalan dengan pernyataan Priyatna (2015: 24) bahwa pandangan patriarki ini membawa konsekuensi dan konsepsi perempuan hanyalah pantulan 
dari konsepsi laki-laki yang menjadi diri.

Dalam hubungan cinta, perempuan sering digambarkan sebagai sosok yang menerima. Suku Sunda mengistilahkannya dulang tinande, yang berarti menerima dan menunggu. Menurut Beauvoir (2016), demi mewujudkan yang diinginkannya pertama-tama yang dilakukannya adalah melayani, merespon keinginan-keinginan kekasihnya, sehingga seorang perempuan akan merasa akan merasa dibutuhkan; ia akan terintegrasikan dengan eksistensi kekasihnya, ia akan turut mendapatkan keberhargaannya, ia akan dijustifikasi. Semakin banyak tuntutan yang diajukan laki-laki, semakin tersanjung perempuan.

\section{SEKSUALITAS DAN RELASI PEREMPUAN DENGAN LAKI-LAKI}

Peristiwa awal dalam sajak ini (sajak lengkap disajikan pada lampiran) terdapat pada bait pertama yang menggambarkan tubuh Kunthi yang telanjang, yang akan/siap menerima persetubuhan dari laki-laki. Di sini digambarkan pula suasana di sekitar Kunthi yang seolah ikut merasakan pengaruh dari peristiwa itu. Ada peristiwa alam yang seolah tahu akan munculnya sebuah peristwa khusus, ada desau angin yang berputar dan ikan yang ikut menggelepar.

Pada bagian berikutnya merupakan peristiwa persetubuhan Kunthi dengan seorang laki-laki. Hal ini terlihat pada bait ketiga dan keempat. Bait ketiga menggambarkan persetubuhan dan bait keempat pengaruh persetubuhan itu terhadap Kunthi. Dia mendapatkan kenikmatan dari hubungan bersetubuh ini yang digambarkan seperti gempa dan badai hingga keluar jerit Kunthi yang merdu dalam kenikmatan. Pada bagian ini terdapat hal yang mengejutkan sebab ternyata Kunthi tidak tahu dan tidak mengenal laki-laki yang menyetubuhinya. Bahkan dia bertanya tentang posisi laki-laki itu, apakah laki-laki itu dewa atau matahari.

Selanjutnya atau pada bagian akhir digambarkan laki-laki itu tidak menyapa Kunthi sama sekali, dia hanya memandang Kunthi lantas pergi menghilang ke sebuah tempat yang tidak diketahui oleh Kunthi. Dan Kunthi kehilangan laki-laki itu juga rasa nikmat yang sekaligus tidak akan pernah dimilikinya.

Sajak ini mempunyai diksi yang menimbulkan bunyi-bunyi merdu sehingga perpaduan kata dengan kata yang membentuk baris sajak semakin menunjukkan harmonisasi bunyi yang sesuai dengan peristiwa yang terjadi dalam sajak.

Judul sajak di atas kedengaran merdu dengan bunyi $u$ dan bunyi aspiran $h$. Apakah bunyi-bunyi merdu pada judul ini akan terus berlanjut pada bait-bait berikut, mengingat judul adalah sebuah jendela untuk memasuki ke dalam sajak yang lebih dalam. Pada bait pertama sajak didominasi oleh bunyi-bunyi yang ringan dan merdu sebagai perpaduan antara bunyi $a$ yang berkombinasi dengan bunyi aspiran $n g$ juga bunyi $u$ yang berkombinasi dengan $h$. Bait pertama yang ringan ini diperkuat dengan bunyi $a$ pada baris terakhir yang berkombinasi dengan bunyi aspiran $h$ sehingga bunyi ringan dan merdu ini membentuk kesan yang penuh gairah. Hal ini diperkuat oleh bunyi-bunyi pada bait kedua yang masih didominasi oleh bunyi $a$ yang ringan dan dikombinasi dengan bunyi aspiran $r$ yang mempunyai efek riang dan gairah.

Pada bait ketiga, bunyi-bunyi itu cukup variatif dan tidak tampak yang dominan. Antara bunyi $i, a, u$,e bergantian mengisi baris demi baris dengan sangat bervariasi. Justru yang sangat kuat pada bait ketiga ini adalah bunyi sampiran. Baris dua dan tiga unsur bunyi itu kuat pada sampiran bunyi $r$ dan pada 
baris tiga bunyi sampiran $t$. Pada baris enam bunyi sampiran yang kuat adalah $l$ sedangkan pada baris tujuh dan delapan bunyi sampiran yang kuat itu pada bunyi $h$. Bunyi yang bervariasi dan tidak didominasi oleh bunyi tertentu menunjukkan suasana yang tidak tentu, menunjukkan rasa yang bermacammacam.

Bunyi yang membawa efek pada suasana tak tentu ini berlanjut pada bait empat namun segera ketidaktentuan itu pada baris-baris berikutnya didominasi oleh bunyi $u$ yang merdu, yang membuat suasana syahdu bahkan lebih dekat kepada suasana sendu. Selain bunyi $u$ yang merdu, pada bait ini terdapat juga bunyi $i$ yang menguatkan efek sendu pada bunyi $u$.

Pada bait lima didominasi oleh bunyi $a$ yang cukup berat yang mengandung ekspresi marah dan bertanya-tanya. Selanjutnya, pada bait berikutnya suasana yang ditimbulkan oleh bunyi-bunyi itu menjadi tenang namun juga suatu kehampaan. Bunyi-bunyi yang kuat yang menggabarkan suasana itu adalah bunyi $i$ pada baris satu dengan kombinasi bunyi aspiran $m$. Pada baris selanjutnya yang menguatkan suasana tenang dan hampa itu adalah bunyi $a$ dengan kombinasi pada aspiran bunyi $h$. Bunyi yang paling kuat yang membawa suasana tenang dan hampa adalah pada baris lima, enam yakni bunyi aspiran $n$.

Pada bait terakhir bunyi yang dominan adalah $i$ yang mengekspresikan kesedihan. Suasana ini adalah sebagai puncak dari suasana yang dibangun sajak sejak awal yang mula-mula riang, terus menuju ketidaktentuan suasana dengan variasi bunyi tertentu, berlanjut pada suasana syahdu dan sendu, yang seterusnya bunyi-bunyi itu mengekspresikan kehampaan, dan diakhiri dengan kesedihan. Suasana kesedihan ini sebagai sebuah ungkapan kehilangan, ketidak- berdayaan karena sesuatu yang tadinya membahagiakan itu tidak bisa dimiliki dan tidak akan pernah dimiliki oleh Kunthi.

Persetubuhan, kata ini membawa imajinasi pada suasana yang riang, bau keringat, semangat menyala, tatapan nanar, bahagia, syahdu, dan semacam semangat berahi dengan gestur-gestur tubuh memikat . Kunthi adalah sebuah nama yang menjadi pelaku persetubuhan itu. Seperti apa persetubuhan itu berjalan, hal ini bisa dilihat pada untaian sajak berikutnya.

Sebelum masuk pada bait pertama, ada pernyataan untuk tarian Sulistyo Tirtokusimo. Hal ini berarti bahwa sajak ditujukan atau sebagai respon pada tarian yang dilakukan atau diciptakan Sulistyo Tirtokusumo. Bait pertama adalah sebuah penggambaran sebelum bersetubuh itu dilakukan. Ada tubuh yang telanjang dan tubuh tersebut begitu memesona yang digambarkan dengan metafor yang telanjang dan berenang pada celah teratai merah. Tubuh itu seperti siap menerima kehadiran seseorang, tubuh yang terbuka seperti celah teratai merah. Pada bait kedua, persetubuhan tengah berlangsung, hal ini bisa dilihat pada metafor ketika desau angin berpusar, yakni sebuah tanda lelaki meisterius itu datang dan memulai persetubuhan dengan Kunthi. Penggambaran tubuh yang memesona dan situasi persetubuhan itu diperkuat dengan suasana di sekitarnya, yakni dengan mengambil bagaimana pengaruh tubuh yang indah itu terhadap yang lainnya. Metafor yang digunakan adalah ikan pun ikut menggeletar. Dalam hal ini, tubuh itu bahkan memberi stimulan berahi pada ikan yang tidak semestinya dirasakan mahluk air itu. Mahluk air itu ikut merasakan suasana persetubuhan, ikut menggeletar. Bait ketiga adalah suasana atau bentuk persetubuhan itu. Di sini bisa dilihat metafor-metafor yang menggambarkan 
persetubuhan itu. /Antara lumut lebat/, /dan tubir batu/adalah penggambaran alat kelamin perempuan yang dirimbuni jembut yang lebat, sedangkan /ada lempang kayu apu/ adalah penggambaran alat kelamin pria yang lurus dan tegak ereksi yang siap melakukan persetubuhan. Baris selanjutnya adalah proses persetubuhan itu yang digambarkan dengan / yang timbul tenggelam/. Hal ini berarti keluar masuknya alat kelamin pria pada alat kelamin perempuan yang terus /meraih/, larus dan buih/ atau berpacu sejalan dengan arus berahi.

Akibat persetubuhan itu tergambar pada bait empat. /Sampai badai dan gempa seperti mеnетриһтu/, hal ini terjadi karena saking nikmatnya akibat persetubuhan pada diri si pelaku, sampai-sampai dilukiskan dengan badai dan gempa sebagai puncak kenikmatan tersebut, saking nikmatnya dan begitu hebat akibatnya pada tubuh yang bersetubuh. Selanjutnya masih dalam kenikmatan itu si kau (Kunthi) berteriak dengan jerit yang merdu, /dan kau teriakan/, /jerit yang merdu $i t u$. Antara berteriak dan menjerit seolah ada peristiwa yang menakutkan atau mengagetkan, peristiwa ini adalah puncak dari kenikmatan bersetubuh sehingga si kau tampak tak bisa mengontrol dirinya, semua diekspresikan dengan jeritan, erangan, jerit kenikmatan sebelum semuanya tenang kembali. Gambaran atau metafor suasana tenang ini dapat dilihat pada baris /sesaat sebelum kulit langit biru/, / kembali, jadi biru/. Artinya bahwa emosi yang semula tenang dan damai ketika memasuki puncak kenikmatan berahi seolah menjadi tidak terkontrol, namun setelah mencapai klimaks semua kembali pada emosi dengan rasa tenang dan damai.

Bait kelima mengandung pengertian si kau bertanya tentang siapa yang telah bersetubuh dengan dirinya. Apakah dewa atau matahari? Jawabannya terdapat dalam bait selanjutnya bahwa laki-laki itu tak pernah diketahui oleh Kunthi. Laki-laki itu menghilang ke tempat asalnya, sebuah tempat yang tak pernah dibayangkan oleh Kunthi, tempat yang hanya ada dalam khayalnya. Dan pada bait terakhir tampak bahwa Kunthi tak akan pernah bisa memiliki laki-laki yang telah menyetubuhinya itu sebab laki-laki itu lenyap untuk selamanya ke sebuah tempat yang tersembunyi, ke sebuah asal //yang tak pernah diacuhkan: //sebuah khayal//di ujung hutan// di ornamen embun/lyang setengah tersembunyi//.

Kunthi atau tokoh kau bersetubuh dengan lelaki yang tak dikenalnya, persetubuhan itu berjalan begitu saja tanpa ada perkenalan terlebih dahulu antara Kunthi dengan lelaki itu. Karena itu Kunthi tidak tahu identitas si lelaki, tetapi Kunthi menikmatinya sepenuh hati sampai pada orgasme. Setelah melakukan persetubuhan itu Kunthi bertanya tentang identitas lelaki tersebut, apakah kau dewa atau matahari demikian pertanyaan Kunthi, tapi lelaki itu cuma diam dan meninggalkannya begitu saja ntah ke dunia mana. Pada akhirnya Kunthi kehilangan bahkan tidak akan pernah bisa memiliki lelaki itu. Di sini pengarang menceritakan Kunthi yang menikmati hubungan seksual dan ditinggalkan lelaki yang menyetubuhinya. Sebuah kisah percintaan yang berat sebelah atau kisah cinta yang pedih, karena sementara Kunthi begitu ingin memiliki dan terus bersama lelaki itu, sedangkan lelaki tersebut setelah merasa puas dengan mereguk kenikmatan bersetubuh lantas pergi, menghilang ke dunia yang tak bisa diikuti oleh Kunthi.

Dipandang dari objek-objek yang dikemukakan, bisa dikatakan bahwa peristiwa ini adalah sebuah kesewenang-wenangan percintaan yang terjadi di alam terbuka. Dikatakan 
kesewenang-wenangan karena tokoh perempuan tidak tahu lelaki yang menyetubuhinya. Dalam hal ini Kunthi menikmatinya meski pada akhirnya harus rela untuk berpisah kembali dengan lelaki itu, berpisah untuk selama-lamanya. Kunthi tidak bisa mengejar lelaki itu karena si lelaki tampak sangat berkuasa dan tak mengindahkan pertanyaan darinya. Di sini Kunthi pada awalnya tampak tidak mengindahkan siapa yang bersetubuh dengan dirinya. Dia terbius oleh kenikmatan bersetubuh, dia juga tidak mempertimbangkan ekses dari perbuatan itu, apakah dosa atau pahala. Si lelaki adalah seseorang yang tidak bertanggung jawab atas yang dilakukannya, begitu mencapai puncak kenikmatan dia langsung pergi tanpa meninggalkan sedikit pun pesan kepada Kunthi yang telah disetubuhinya.

Ricoeur via Kleden (1990:108) menyebutkan bahwa sebuah karya mempunyai referensi yang bersifat deskriptif atau menyangkut sesuatu yang empiris, dan dapat bersifat puitis kalau menyangkut dunia nonempiris, tetapi dunia yang potensial, yang mungkin dibangun, dan masih harus dibangun. Dalam pada itu referensi deskriptif tidak selalu bersifat ostensif dalam arti menyangkut suatu lingkungan konkret, tetapi dapat berupa suatu dunia empiris yang tidak dapat dirujuk kepada suatu tempat dan waktu tertentu. Menurut Ricoeur hal ini menandai pertemuan antara dunia yang disarankan oleh sebuah teks dan dunia kongkret pembaca atau pendengar; disebut pembauran cakrawala.

Sebuah teks yang dibaca, sebuah kisah yang diceritakan, menawarkan sebuah dunia potensial. Jadi, bila seorang pembaca atau pendengar menerima dan sungguh menghayati sebuah cerita, maka ia mempertemukan dunia yang dianjurkan oleh kisah itu dengan dunia hidupnya yang kongkret dan dengan itu terjadilah pembauran horizon. Dengan kata lain tujuan terakhir setiap penafsiran adalah eksistensi manusia: manusia menafsir diri dalam terang sebuah teks.

Sehubungan dengan referensi di atas maka sajak Goenawan yang dianalisis adalah wacana puitik yang mengacu ke dunia yang mungkin untuk diaktualisasikan, dunia ketika orang dapat berdiam dan merealisasikan potensialitasnya sendiri atau lebih menghubungkannya secara intertekstual.

Secara tekstual sajak ini berbicara tentang persetubuhan Kunthi dengan laki-laki yang tidak dikenalnya. Persetubuhan itu sangat dinikmati oleh Kunthi meski pada akhirnya dirinya tetap tidak mengenal laki-laki itu bahkan ketika laki-laki itu meninggalkannya dan tidak bisa dimilikinya. Secara intertektual sajak merujuk pada cerita Mahabharata.

Sajak "Persetubuhan Kunti" adalah sajak yang merujuk pada teks bertemunya Dewi Kunthi dengan Batara Surya yang terdapat dalam kisah Mahabharata. Kunti adalah puteri Prabu Kuntiboja yang bersaudarakan Basudewa dan merupakan ayah dari Baladewa, Kresna dan Sumbadra. Ia juga adalah ibu dari Yudistira, Bima, dan Arjuna dari suaminya Pandu Dewanata. Selain itu, Kunti juga ibunya Karna dari Dewa Surya.

Peristiwa dalam sajak sangat berkaitan dengan proses lahirnya Karna, seorang pahlawan perang Bharatayuda, saudara tertua Pandawa dari Dewi Kunti yang berada di pihak Hastina (Kurawa) ketika melawan Amarta (Pandawa). Penyebab awal kelahiran Karna adalah akibat kelalaian Kunthi dalam menggunakan ilmu Druwasa, yakni ilmu yang bisa mengundang dewa yang dikehendakinya ketika menginginkan anak. Pada saat ketika mendapat ilmu tersebut Kunthi penasaran dan pada usianya yang masih belia itu dia mencoba memanggil Batara Surya. Yang diundang 
datang dan Kunthi terkejut lantas memohon ampun karena dirinya sedang mencoba ilmu barunya dan tidak berniat untuk mempunyai anak. Tapi karena ilmu tersebut telah sanggup menerbitkan hasrat seksual dewa maka dibuahinya Kunthi yang masih muda tersebut. Pada akhirnya ia pun mengandung anak dari Batara Surya. Berkat kesaktian dewa itu Kunthi tidak melahirkan secara konvensional tapi anak itu dilahirkan melalui telinga. Kemudian anak tersebut diberi nama Karna dan kelak akan menjadi pahlawan perang tanpa tanding karena kesaktiannya yang sangat tinggi dengan berbekal senjata Konta yang bisa mematikan siapapun lawannya.

Proses Batara Surya membuahi Kunthi adalah proses yang tidak lazim sebagaimana yang dilakukan manusia tetapi dalam sajak "Persetubuhan Kunti" persetubuhan itu digambarkan sebagaimana manusia melakukannya. Ada gambaran kenikmatan yang dirasakan oleh Kunthi hingga dirinya merasakan nikmat bersetubuh sampai klimaks (orgasme). Tetapi setelah itu dirinya ditinggalkan dan tidak bisa memiliki laki-laki yang datang kepadanya. Dalam hal ini sajak "Persetubuhan Kunti" mengungkapkan relasi laki-laki perempuan setidaknya dalam dua hal. Pertama, sikap laki-laki yang berkuasa dan kedua sikap perempuan yang dikuasai. Lakilaki diundang kemudian datang kepada Kunthi, menyetubuhi, menikmati, dan menghilang meninggalkan Kunthi. Sedangkan Kunthi mengundang, didatangi, disetubuhi, menikmati, dan ditinggalkan.

Seperti disebutkan sebelumnya bahwa usia Kunthi pada saat disetubuhi oleh Batara Surya adalah usia yang sangat muda. Pada usia ini menurut Beauvoir (1989), perempuan dalam kebimbangan terhadap keberadaan tubuhnya, tepatnya organ seksualnya. Ada rasa kepenasaran yang besar juga ketakutan dan rasa jijik terhadap hasrat seksual. Karena itu perempuan ini mudah diombang-ambing, baik untuk dibujuk ke dalam hasrat seksual maupun dibujuk untuk bersikap benci atau jijik terhadap seksualitas. Dalam mitos Mahabharata, Kunthi diberi ilmu yang bisa mengundang dewa mana pun yang diinginkannya dalam rangka menghendaki keturunan. Karena kemudaannya dan tidak mempunyai pengetahuan yang cukup tentang seksualitas, hal ini menimbulkan rasa kepenasaran yang besar terhadap dirinya untuk menggunakan ilmu tersebut dalam rangka mengundang Dewa Batara Surya. Keberanian ini bukan semata-mata karena Kunthi menginginkan berhubungan seks tetapi lebih dipicu oleh rasa penasarannya terhadap misteri seksualitas. Di sini, Kunthi selanjutnya mengalami inisiasi seksual. Dalam kisah Mahabharata, Kunthi meskipun tidak mau tapi terpaksa harus melayani atau mau menerima hasrat seksual dewa yang diundangnya. Dalam kerangka ini Beauvoir (1989:147) menyebutkan bahwa perempuan dipenetrasi dan dibuahi melalui vagina, yang menjadi pusat erotis hanya dengan keikutsertaan laki-laki, dan proses ini hampir selalu berupa semacam penyerangan. Bentuk inilah yang kemudian mengubah gadis menjadi perempuan yang kemudian dirinya bisa menikmati hubungan seksual.

Ketika dewa mendapat undangan dari perempuan dan darinya memunculkan hasrat seksual selanjutnya dewa tidak bisa meninggalkan perempuan itu sebelum hasratnya terpenuhi. Hal ini menunjukkan bahwa lakilaki harus memperoleh seks dari perempuan yang diinginkannya, atau cinta bagi laki-laki harus disertai hubungan seks. Menurut Simone de Beauvoir (1989:520), bagi laki-laki per- 
setubuhan yang mencapai ejakulasi membebaskan dirinya dari suatu ketidaknyamanan sekresi; ia mendapat pelepasan secara menyeluruh setelah gairah seksual yang selalu disertai kenikmatan. Berbeda dengan perempuan, seks tidak terlalu penting, tetapi yang dibutuhkan adalah cinta. Untuk mendapatkan cinta ini, perempuan tidak ragu-ragu mengorbankan atau menyerahkan dirinya untuk disetubuhi oleh laki-laki. Karena itu, Kunthi akhirnya mau disetubuhi oleh Batara Surya bahkan sampai mendapatkan anak darinya.

Orgasme adalah puncak kenikmatan yang didapatkan ketika hasrat seksual muncul dan mendapat bentuk pemenuhan. Bentuk pemenuhan itu bisa melalui persetubuhan atau masturbasi. Jika dalam persetubuhan, keadaan orgasme yang ideal adalah terpenuhinya hasrat itu melalui pasangannya ketika bersetubuh. Hal ini biasanya tidak setiap pasangan mengalaminya sebab ada hal-hal tertentu yang cukup kuat memengaruhi proses persetubuhan. Pada sajak ini, Kunthi bersetubuh dengan Batara Surya. Dalam mitos, pada saat itu Kunthi masih gadis yang belum berpengalaman dalam kegiatan seksual. Pilihannya terhadap dewa adalah pemilihan terhadap pasangan yang lebih tua usianya dari dirinya. Dalam psikoanalisis Freud via Calvin S. Hall, hal ini merupakan kewajaran, karena biasanya perempuan muda biasanya akan memilih lakilaki yang usianya lebih tua sebagai bentuk pencarian rasa aman sebagai pengganti sosok bapak, begitu juga dengan laki-laki muda biasanya memilih perempuan yang lebih tua sebagai pengganti sosok ibunya. Dalam kaitan ini menurut Beauvoir (1989:525), perempuan biasa terpenjara dalam lingkup keluarga, diperuntukkan bagi laki-laki sejak masih kanak-kanak, dan terbiasa melihat laki-laki sebagai sosok absolute. Karena itu, perempuan bermimpi mentransendenkan dirinya pada salah satu mahluk paling superior, menjadikan dirinya satu dengan subjek yang merdeka ini dengan cara menyerahkan dirinya kepada lakilaki yang merepresentasikan diri sebagai sosok absolut yang esensial. Dengan kata lain bahwa ketika Kunthi orgasme, //dan kau teriakan//jerit yang merdu itu//, terjadi penyerahan yang total sekaligus menikmatinya, bahkan kekaguman atau kepuasan yang didapatkannya itu seolah-olah tidak dipercayainya. Sehingga Kunthi mengajukan pertanyaan, // Engkau dewa? kau bertanya// Engkau matahari//. Pertanyaan itu menghendaki jawaban yang bisa meyakinkannya bahwa pasangannya yang telah menyetubuhinya itu seseorang yang betul-betul punya posisi yang kuat.

Meskipun persetubuhan menimbulkan rasa nikmat bagi Kunthi tetapi sebagai perempuan dia tampak tersubordinasi. Lakilaki yang datang itu meninggalkan Kunthi setelah puas menikmati tubuhnya dan Kunthi tidak bisa mengikat lebih lama lagi meskipun dirinya sebagai pengundang. Hal ini berarti, pertama, laki-laki itu akan bertahan jika hasrat seksualnya belum terpenuhi. Kedua, laki-laki akan meninggalkan jika hasrat seksual telah terpenuhi. Ketiga, perempuan mengharapkan kehadiran laki-laki disisinya secara terus menerus sebagai bentuk harapan akan terciptanya rasa aman, dalam arti memerlukan Kenyamanan dari kehadiran itu dan tindakan seksual normal membawa perempuan kepada ketergantungan terhadap laki-laki. Dari tiga poin ini terlihat bahwa perempuan dapat diambil laki-laki kapan saja, sementara si lakilaki mengambil perempuan hanya bila ia dalam keadaan ereksi karena persetubuhan bisa dilakukan jika ada hasrat dari laki-laki, dan kepuasan merupakan tujuan akhir yang alami. 
Laki-laki itu diam sebelum menghilang//

ke sebuah asal// yang tak pernah

diacuhkan:// sebuah khayal// di ujung

hutan//di ornamen embun//yang setengah

tersembunyi.// Yang tak pernah kau miliki,

Kunthi,// tak akan kau miliki.//

(Goenawan Mohamad, 2001:161)

Bait di atas merupakan kelanjutan dari pertanyaan Kunthi tentang siapa laki-laki yang telah bersetubuh dengannya. Tidak ada jawaban dari laki-laki tersebut. Laki-laki itu hanya diam kemudian menghilang ke sebuah tempat yang tidak bisa dijangkau. Bait ini adalah sebuah metafor yang mengungkapkan bahwa laki-laki sangat berkuasa dan bisa seenaknya meninggalkan pasangannya selepas hasrat seksualnya terpenuhi. Padahal si perempuanlah yang mengundang laki-laki itu untuk datang. Artinya, posisi tawar perempuan menjadi rendah setelah tubuhnya dimanfaatkan oleh laki-laki, sedangkan laki-laki mempunyai daya tawar yang kuat ketika dirinya telah menuntaskan hasratnya terhadap perempuan. Sebenarnya perempuan mempunyai daya tawar yang kuat sebelum tubuhnya disentuh laki-laki. Ini terlihat manakala laki-laki itu menginginkan pelepasan hasratnya terhadap perempuan, dirinya tidak beranjak atau tidak mau meninggalkan perempuan sebelum semua terpenuhi.

Hal menarik dari sajak ini, perempuan itu menikmati persetubuhan bahkan sampai klimaks meskipun dirinya tidak begitu mengenal siapa sesungguhnya laki-laki itu. Yang berbeda dengan laki-laki adalah jika laki-laki tidak mau terikat selepas persetubuhan, sedangkan perempuan tetap menghendaki laki-laki itu menjadi miliknya karena dirinya telah mengorbankan jiwa dan raganya. Dengan kata lain, perempuan telah menjadi korban kesewenangan laki-laki meskipun perempuan itu menikmati hubungannya. Perempuan menjadi tersubordinasi dan tidak bisa memiliki laki-laki seperti yang terlihat pada bait akhir, //yang tak pernah kau miliki, Kunthi,//tak akan kau miliki//. Sedangkan laki-laki tetap bisa memiliki perempuan sepanjang dirinya mau atau lakilaki bisa memiliki perempuan karena aktivitasnya sedangkan perempuan tidak bisa memiliki karena pasivitasnya.

Yang tidak kalah pentingnya dari posisi laki-laki perempuan itu adalah bahwa laki-laki yang menyetubuhi Kunthi adalah dewa. Artinya, selain mempunyai kekuasaan sebagai laki-laki dia juga mempunyai kekuasaan sebagai dewa. Banyak diceritakan bahwa dewa mempunyai anak di alam madyapada, dan hal ini bukan sebagai suatu kesulitan. Sebagai penguasa, dirinya sangat gampang untuk mendapatkan perempuan dan sangat gampang untuk meninggalkan perempuan. Jadi, ada dua kelemahan sekaligus dari perempuan. Pertama, kelemahan dari lakilaki, dan kedua, kelemahan dari penguasa. Untuk penguasa, hal ini tidak saja berlaku bagi dewa-dewa tetapi berlaku juga bagi penguasa dari golongan manusia. Raja-raja tradisional hampir selalu mempunyai istri lebih dari satu. Ini menunjukkan bahwa penguasa laki-laki sangat dominan posisinya dibanding perempuan.

Dunia yang mungkin dan ditawarkan dalam sajak adalah laki-laki dan perempuan mempunyai kedudukan yang sama dalam urusan seksual. Hal ini terlihat ketika Kunthi menikmati persetubuhan itu sampai orgasme, demikian juga dengan laki-laki. Sajak ini menawarkan juga sebuah dunia untuk tidak percaya kepada lakilaki karena laki-laki hanya bisa mengambil dan menikmati perempuan tanpa pernah berpikir 
untuk memberi perlindungan atau membahagiakan perempuannya. Laki-laki memerlukan perempuan hanya dalam urusan hubungan seksual, yakni ketika dirinya ereksi dan menghendaki pemenuhan yang sempurna dari vagina basah perempuan.

\section{SIMPULAN}

Hasil penelitian menunjukkan bahwa sajak mengungkapkan hubungan yang saling menikmati tetapi keduanya mempunyai perbedaan. Laki-laki mempunyai peranan aktif dalam menentukan arah dan menikmati perempuan lantas degan mudah meninggalkannya karena sudah tidak memerlukannya, sedangkan perempuan menikmati laki-laki tapi harus ditinggalkan laki-laki setelah dirinya tidak diperlukan. Selain itu, sajak ini mengungkapkan bahwa penguasa/ lelaki selalu mempunyai tabiat untuk bertindak sewenang-wenang menurut kesukaan dirinya.

Sajak "Persetubuhan Kunthi" menunjukkan juga bahwa posisi perempuan itu lemah dan tersubordinasi. Dalam hal ini, perempuan hanyalah korban dan nasibnya ditentukan oleh laki-laki meskipun dalam perjumpaannya dalam kebersatuannya perempuan juga menikmati. Perempuan dalam hal ini adalah mahluk yang menunggu, menikmati/ dinikmati, dan ditinggalkan, sedangkan lakilaki ditunggu, menikmati/ dinikmati, dan meninggalkan. Persamaan relasi keduanya yakni saling menikmati dan dinikmati sedangkan perbedaannya laki-laki lebih menentukan proses aktivitas tersebut dan setelahnya sedangkan perempuan menerima atau menunggu sesuatu yang dilakukan oleh laki-laki supaya dirinya ada dan berfungsi. Selain itu, laki-laki menunjukkan makhluk yang arogan dan tidak bersimpati terhadap perempuan. Di sini, perempuan hanyalah objek yang mesti dinikmati dan tidak untuk dijadikan teman yang mempunyai derajat relasi yang sejajar.

\section{DAFTAR PUSTAKA}

Beauvoir, S. de. (2003). The Second Sex. Kehidupan Perempuan. Surabaya: Pustaka Promethea

Beauvoir, S. de. (2003). The Second Sex. Fakta dan Mitos. Surabaya: Pustaka Promethea

Culler, J. (1977). Structuralist Poetics. London: Methuen \& Co. Ltd.

Kleiden, I. (2005). Sastra Indonesia dalam Enam Pertanyaan. Esai-esai Sastra dan Budaya. Jakarta: Pustaka Utama Grafiti

Mohamad, G. (2001). Sajak-sajak Lengkap 1961-2001. Jakarta: Metafor Publising

Pendit, N. S. (2005). Mahabharata. Jakarta: Gramedia Pustaka Utama

Pendit, N. S. (2005). Bharatayudha. Jakarta: Gramedia Pustaka Utama

Pradopo, R. D. (2003). Pengkajian Puisi. Yogyakarta: Gadjah Mada University Press

Priyatna, A. (2015). Perempuan dalam Tiga Novel Karya Nh. Dini. Bandung: Matahari.

Selden, R. (1993). Panduan Pembaca Teori Sastra Masa Kini. Yogyakarta: Gajah Mada University Press.

Ratih, R. (1994). Pendekatan Intertekstual dalam Penelitian Sastra dalam Teori

Penelitian Sastra, Jabrohim (ed.). Yogyakarta: Masyarakat Poetika Indonesia IKIP Yogyakarta.

Riffaterre, M. (1978). Semiotic of Poetry. London: Metheun \& Co. Ltd. 


\section{Lampiran Puisi:}

\section{PERSETUBUHAN KUNTHI}

untuk tarian Sulistyo Tirtokusumo

Semakin ke tengah tubuhmu

yang telanjang

dan berenang

pada celah teratai merah.

Ketika desau angin berpusar

ikan pun

ikut menggeletar.

Dari pinggir yang rapat

membaur ganggang.

Antara lumut lebat

dan tubir batu

ada lempang kayu apung

yang timbul tenggelam

meraih

arus dan buih.
Sampai badai dan gempa seperti

menempuhmu

dan kau teriakkan

jerit yang merdu itu

sesaat sebelum kulit langit biru

kembali, jadi biru.

Engkau dewa? kau bertanya

Engkau matahari?

Laki-laki itu diam sebelum menghilang ke sebuah asal

yang tak pernah diacuhkan:

sebuah khayal

di ujung hutan

di ornamen embun

yang setengah tersembunyi.

Yang tak pernah kau miliki, kunthi, tak akan kau miliki.

1996

diksi Volume 28, Nomor 1, Maret 2020 